\title{
PENGEMBANGAN KARTU BERGAMBAR TIGA DIMENSI SEBAGAI MEDIA PEMBELAJARAN MENULIS TEKS BERITA
}

\author{
Dian Anggoro Widiatmoko, Nina Widyaningsih, Yanuar Bagas Arwansyah \\ dian.anggoro.widiatmoko@gmail.com,ninawidyaningsiih@gmail.com, \\ yanuarbagasa@upy.ac.id \\ Universitas PGRI Yogyakarta
}

*Diterima: 14 Juli 2020, Disetujui: 06 Agustus 2020

\begin{abstract}
This study aims: 1) To develop a three-dimensional pictorial card learning media on Indonesian language teaching and learning activities in writing news text material; 2) find out the quality of three-dimensional picture card learning media in Indonesian teaching and learning activities in writing news text based on expert judgment; 3) determine the attractiveness of three-dimensional pictorial card learning media on Indonesian teaching and learning activities in writing news texts; and 4) knowing the effectiveness of three-dimensional picture cards in teaching and learning activities in Indonesian with written news text material. This research method is the development of the Borg and Gall model with the object of research is class VIII SMP N 1 Pleret Bantul Academic Year 2018/2019. The results of this study produce three-dimensional illustrated card learning media products for teaching and learning media writing news texts. The quality of three-dimensional picture cards for teaching and learning media writing news texts based on the assessment of media experts scored 71 with an average of 3.73 with very good qualifications, the value of the material experts scored 68 with a mean of 4 with very good qualifications. The attractiveness of student responses was 53.7 with a percentage of $94 \%$ with very good ratings. Student test results using effective three-dimensional pictorial card media with results showing different and significant averages. Keywords: Learning Media, Three Dimensional Picture Cards, Writing News Texts
\end{abstract}

\begin{abstract}
Abstrak
Penelitian ini bertujuan: 1) Untuk melakukan pengembangan media pembelajaran kartu bergambar tiga dimensi pada kegiatan pembelajaran Bahasa Indonesia dalam materi menulis teks berita; 2) mengetahui kualitas media pembelajaran kartu bergambar tiga dimensi pada kegiatan pembelajaran Bahasa Indonesia materi menulis teks berita berdasarkan penilaian ahli; 3) mengetahui daya tarik media pembelajaran kartu bergambar tiga dimensi pada kegiatan pembelajaran Bahasa Indonesia materi menulis teks berita; dan 4) mengetahui efektivitas kartu bergambar tiga dimensi pada kegiatan pembelajaran Bahasa Indonesia materi menulis teks berita. Metode dalam penelitian ini adalah pengembangan dengan model Borg and Gall dengan objek penelitian adalah kelas VIII SMP N 1 Pleret Bantul Tahun Ajaran 2018/2019. Hasil penelitian ini menghasilkan produk media pembelajaran kartu bergambar tiga dimensi untuk media kegiatan pembelajaran menulis teks berita. Kualitas kartu bergambar tiga dimensi untuk media kegiatan pembelajaran menulis teks berita berdasarkan penilaian ahli media mendapat skor 71 dengan rerata 3,73 dengan kualifikasi sangat baik, nilai dari ahli materi mendapat skor 68 dengan rerata 4 dengan kualifikasi sangat baik. Daya tarik respon siswa mendapatkan nilai 53,7 dengan nilai persentase $94 \%$ dengan penilaian sangat baik. Hasil tes siswa menggunakan media kartu bergambar tiga dimensi efektif dengan hasil menunjukkan rata-rata yang berbeda dan signifikan.

Kata kunci: Media Pembelajaran, Kartu Bergambar Tiga Dimensi, Menulis Teks Berita
\end{abstract}




\section{PENDAHULUAN}

Pendidikan merupakan usaha yang disadari dan terencana guna memunculkan iklim pembelajaran yang menjadikan siswa atau peserta didik secara aktif mengembangkan potensi diri guna memeroleh kekuatan unutk mengendalikan diri, pemikiran, sikap, spiritual keagamaan, kepribadian, dan juga keterapilan yang dibutuhkan untuk diri sendiri, lingkungan, bangsa dan Negara (UU No 20 Tahun 2003). Pendidikan merupakan pilar pembangun bangsa. Melalui pendidikan tujuan dan cita-cita sebuah negara dapat dicapai.

Salah satu unsur pendidikan yang tidak dapat digantikan oleh peran lain adalah guru. Guru memiliki peran penting dalam mewujudkan tujuan pendidikan. Tugas guru tidak hanya menjadi pengajar atau agen pentransfer ilmu. Jika hanya menyampaikan ilmu pengetahuan maka kecanggihan teknologi dapat menggantikan perannya. Ada empat kompetensi yang harus dikuasai guru agar menjadi pendidik yang profesional. Ditambah dengan era disrupsi dan perkembangan teknologi saat ini, guru harus mampu bertransformasi menjadi agen perubahan yang adaptif.

Sadirman (2012:146) mengatakan bahwa peranan guru salah satunya adalah sebagau fasilitator. Guru harus memfasilitasi kegiatan pembelajaran yang berpusat pada siswa dan mengembangkan kemampuan berpikir kritis mereka. Guru dituntut mampu menciptakan suasana belajar yang mudah saat kegiatan pembelajaran, semisal dengan memunculkan suasana belajar yang aktif sehingga tercipta proses pembelajaran efektif dan menyenangkan. Banyak faktor yang menunjang keberhasilan dalam pembelajaran, media pembelajaran adalah satu di antaranya. Kegunaan utama media pembelajaran yakni untuk menciptakan sarana yang dipergunakan membantu proses pembelajaran yang dibuat oleh guru. Melalui media pembelajaran keterbatasan-keterbatasan dalam proses pembelajaran dapat dikurangi. Selain itu, siswa juga lebih termotivasi mengikuti pembelajaran.

Pembelajaran bahasa Indonesia mencakup empat keterampilan berbahasa yakni menyimak, berbicara, membaca, serta menulis. Pembelajaran bahasa Indonesia berkaca dari kurkulum 2013 dirancang menjadi pembelajaran berbasis teks. Sistem ini diharapkan mampu menjadikan siswa memiliki kompetensi yang komprehensif pada empat keterampilan tersebut. Siswa mampu memiliki kemampuan aktif reseptif melalui kemampuan menyimak dan membaca serta aktif produktif melalui kemampuan berbicara dan menulis.

Pada kurikulum 2013 terdapat kompetensi yang diwajibkan tercapai oleh siswa kelas VIII pada kegiatan belajar mengajar Bahasa Indonesia yaitu kemampuan menulis teks berita. Materi menulis teks berita ada di dalam KD 4.2 yaitu menulis teks berita sesuai dengan karateristik teks yang dibuat baik secara lisan maupun tulisan. Materi tersebut penting dikuasai oleh siswa. Melalui teks berita siswa akan terlatih bagaimana memeroleh berita, mengolah, mengemas, dan menyajikan atau mengomunikasikan sebuah berita lewat lisan dan tulisan.

Berdasarkan hasil wawancara dan observasi yang penulis laksanakan bersama guru bahasa Indonesia di SMP Negeri 1 Pleret terdapat beberapa permasalahan yang memengaruhi keterapilan siswa kelas VIII SMP pada materi menulis teks berita. Permasalahan tersebut terangkum menjadi empat faktor utama, yaitu (1) siswa memiliki kemampuan yang minim dalam mengungkapkan pikiran, ide, dan gagasan dalam bentuk tulisan, (2) latar belakang sosial ekonomi siswa yang memiliki pengaruh pada hasil tulisan mereka, (3) belum dibuat atau digunakannya media pembelajaran yang bisa digunakan peserta didik untuk membantu pada pembelajaran menulis teks berita, dan (4) kemampuan guru yang terbatas dalam penggunaan media pembelajaran serta guru membutuhkan media pembelajaran kreatif dan mudah 
dalam pemakaiannya serta mempermudah peserta didik dalam kegiatan belajar mengajar menulis teks berita.

Permasalahan dalam kegiatan belajar mengajar menulis teks berita di atas memerlukan solusi yang tepat. Diperlukan media pembelajaran kreatif dan inovatif untuk mendukung proses pembelajaran. Banyak jenis media pembelajaran. Salah satunya adalah media berbentuk tiga dimensi. Media pembelajaran tiga dimensi merupakan benda nyata atau diwujudkan sebagai gambar tiga dimensi. Media yang dikembangkan untuk penelitian ini adalah kartu bergambar tiga dimensi yang merupakan kumpulan kartu bergambar yang didesain tiga dimensi yang di dalamnya berisi gambar dan kumpulan kata kunci untuk merangsang siswa agar bisa menulis berita sesuai dengan kartu apa yang ia dapatkan.

Berdasarkan latar belakang permasalahan yang telah diuraikan dapat dirumuskan permasalahan berikut: 1) Bagaimanakah pengembangan media pembelajaran kartu bergambar tiga dimensi pada pembelajaran Bahasa Indonesia materi menulis teks berita kelas VIII SMP N 1 Pleret Bantul Tahun Ajaran 2018/2019?; 2) Bagaimanakah kualitas media pembelajaran kartu bergambar tiga dimensi pada pembelajaran Bahasa Indonesia materi menulis teks berita kelas VIII SMP N 1 Pleret Bantul Tahun Ajaran 2018/2019?; 3) Bagaimanakah daya tarik siswa terhadap kartu bergambar tiga dimensi sebagai media dalam kegiatan belajar mengajar menulis teks berita siswa kelas VIII siswa SMP Negeri 1 Pleret Bantul Tahun Ajaran 2018/2019?; 4) Bagaimana efektivitas media pembelajaran kartu bergambar tiga dimensi pada kegiatan belajar mengajar Bahasa Indonesia materi menulis teks berita kelas VIII SMP N 1 Pleret Bantul Tahun Ajaran 2018/2019?

\section{KAJIAN LITERATUR}

Teks berita menurut Rahman (2018:47) merupakan teks yang mengungkapkan informasi tentang peristiwa atau kejadian yang telah atau sedang terjadi. Menurut Simarmata dkk. (2020:32) struktur teks berita terdiri dari tiga bagian yaitu, judul berita, teras berita, dan tubuh berita. Judul berita berfungsi memberikan preferensi awal tentang isi informasi yang disampaikan. Teras berita menyajikan ringkasan hal yang akan disampaikan. Sementara tubuh berita berisi informasi tentang peristiwa atau kejadian yang menyangkut $5 \mathrm{~W} 1 \mathrm{H}$ (what, who, when, where, why dan how). Sementara itu terdapat lima kaidah kebahasaan teks berita (Rahman, 2018:48-49). Pertama, fokus pada peristiwa dan bukan pelaku. Kedua, menggunakan verba pewarta yang berisikan kalimat informasi. Ketiga, menggunakan verba transitif. Keempat, menggunakan kalimat langsung dan tak langsung. Kelima, terdapat penjelasan waktu dan tempat terjadinya peristiwa.

Media menurut Sumiharsono dan Hasanah (2017:3) berasal dari bahasa latin medium yang berarti sarana, perantara atau pengantar. Arsyad (2017:4) menyatakan bahwa media merupakan alat penyalur pesan antar individu sehingga dapat memancing seseorang untuk bereaksi dan dari hal tersebut muncul keinginan belajar. Pendapat senada disampaikan Anitah (2010:1) bahwa media merupakan sarana untuk menghubungkan semua pihak yang terlibat dalam sebuah hubungan. Berdasarkan paparan pakar di atas dapat disimpulkan bahwa media merupakan sarana, perantara, dan pengantar yang menghubungkan semua pihak yang terlibat dalam sebuah interaksi.

Jika dikaitkan dengan pembelajaran maka media pembelajaran adalah perangkat yang dipergunakan guru untuk membantu menjalin interaksi dengan siswa berkaitan dengan materi pembelajaran. Hal ini didukung pendapat Riyana (2012:6) bahwa media pembelajaran berperan penting dalam proses interaksi guru dan siswa. 
Pemahaman siswa terhadap pesan yang diberikan guru terlihat dari umpan balik yang diberikan siswa. Jika umpan balik yang diberikan positif maka media yang digunakan baik. Hal serupa juga terjadi jika media yang digunakan tidak tepat maka umpan balik siswa menjadi negatif.

Penggunaan media pembelajaran adalah sebuah keniscayaan dalam pembelajaran. Jalinus dan Ambiyar (2016:6) menyatakan bahwa berdasarkan hasil simpulannya dari pendapat para pakar setidaknya diperoleh empat fungsi media pembelajaran yaitu, atensi, afektif, kognitif, dan kompensatoris. Konteks fungsi atensi adalah dalam pembelajaran media berfungsi menarik perhatian siswa. Sementara itu, media pembelajaran juga mengubah sikap siswa. Hal tersebut dapat dilihat dari perilaku saat kegiatan pembelajaran. Dengan media yang baik biasanya siswa akan tenang dan memerhatikan pelajaran. Media pembelajaran yang tepat akan membantu sisi kognitif siswa. Media pembelajaran dapat mengatasi keterbatasan penjelasan yang disampaikan melalui verbal saja (ceramah). Selain itu, untuk siswa dengan tingkat pemahaman rendah, media pembelajaran membantu mereka untuk merekognisi kembali pesan yang disampaikan guru lewat gambar, video, animasi, dll.

Penggunaan media gambar tiga dimensi merupakan salah satu solusi untuk meningkatkan pengetahuan, sikap, dan keterampilan siswa. Beberapa penelitian menunjukkan bahwa media gambar tiga dimensi efektif untuk digunakan dalam pembelajaran. Misalnya penelitian yang dilakukan Umayah dkk (2013) tentang pengembangan kartu bergambar tiga dimensi pada pembelajaran IPA. Dari hasil penelitian dapat simpulkan bahwa Kartu bergambar tiga dimensi yang dikembangkan layak digunakan sebagai media pembelajaran IPA terpadu dengan rata-rata skor $89,84 \%$, dikatakan layak karena sesuai dengan indikator pencapaian diatas $81 \%$, dan Kartu bergambar tiga dimensi yang dikembangkan dikatakan efektif digunakan dalam pembelajaran IPA terpadu yang ditunjukkan dari peningkatan nilai $\mathrm{N}$-gainnya yaitu 0,52 .

Penelitian serupa dilakukan oleh Azizah (2016). Hasil penelitian menunjukkan pengembangan media buku bergambar mempermudah guru dalam kegiatan belajar mengajar bahasa Indonesia pada materi puisi. Hasil tersebut menunjukkan media tersebut dapat membantu guru pada penyampaian materi dan memperoleh persentase nilai $100 \%$. Adapun evaluasi media pembelajaran mampu meningkatkan kemampuan peserta didik dalam penulisan puisi sehingga memeroleh persentase $100 \%$. Kesesuaian isi materi dengan SK-KD juga memeroleh nilai persentase $100 \%$. Kesimpulan dari penelitian tersebut media pembelajaran layak digunakan dan dikembangkan sesuai dengan materi menulis puisi pada kelas $3 \mathrm{Ml}$ (Madrasah Ibtidaiyah).

\section{METODE PENELITIAN}

Penelitian ini menggunakan metode $\mathrm{R}$ \& $\mathrm{D}$ (research and development). Sugiyono (2017:407) menyatakan bahwa pengembangan merupakan metode yang bertujuan menciptakan produk yang akan dipergunakan untuk tujuan tertentu dengan menguji kelayakan produk tersebut terlebih dahulu. Penelitian ini menggunakan model pengembangan atau $R$ \& $D$ dari Borg and Gall.

Berdasarkan model pengembangan dari Borg and Gall, tahap dalam pengembangan dilaksanakan melalui beberapa langkah berikut: (1) penelitian dan pengumpulan data, (2) perencanaan, (3) pengembangan draft produk awal, (4) uji coba lapangan awal, (5) revisi hasil uji coba, (6) uji lapangan produk utama, (7) revisi produk, (8) uji coba lapangan skala luas/uji kelayakan, (9) revisi produk final, (10) Desiminasi dan implementasi. 
Desain uji coba pada penelitian ini divisualisasikan sebagai berikut:

$$
\mathrm{O}_{1} \mathrm{X} \mathrm{O}_{2}
$$

Gambar 4. Desain Eksperimen (sebelum-sesudah) (Sugiyono, 2017: 74)
Keterangan:
$\mathrm{O}_{1}$ : Perolehan nilai Pretest
$\mathrm{O}_{2}$ : Perolehan nilai Postest

Subjek dalam penguji cobaan produk merupakan peserta didik kelas VIII SMP Negeri 1 Pleret. Jumlah keseluruhan dari subjek penelitian ini yaitu 36 peserta didik dengan rincian 6 orang dalam pengujian kelompok kecil dan 30 orang dalam pengujian skala besar.

Teknik pengumpulan data yang diterapkan pada penelitian ini yakni menggunakan angket dan tes. Angket yang digunakan pada penelitian ini yaitu angket ahli materi, ahli media, dan angket respons siswa. Angket yang digunakan berbentuk skala linkert yaitu validasi ahli materi, angket validasi ahli media, dan angket ahli pembelajaran. Skala Linkert yang digunakan, yaitu 1 (sangat kurang baik), 2 (kurang baik), 3 (cukup), 4 (baik), dan 5 (sangat baik). Penilaian angket respon siswa menggunakan skala Guttman yaitu "ya" dan "tidak", sebab dengan menggunakan penilaian tersebut akan memudahkan siswa.

Tes ini dilaksanakan dengan menggunakan satu kelas sampel, sehingga model yang dipergunakan pada tes ini yaitu desain eksperimen One Grup Pretest-Postest Design untuk menunjukan keefektifan dalam pembelajaran setelah mengunakan media berbasis kartu bergambar tiga dimensi.

Adapun desain One Grup Pre-test Post-test Design dari Borg and Gall terdiri atas tiga langkah, yakni: 1) melakukan pre-test guna melakukan pengukuran variabel terkait. 2) melakukan eksperimen, dan 3) melakukan post-test guna melakukan pengukuran hasil perlakuan pada variabel terkait. Berdasar hal tersebut maka dampak perlakuan ditentukan dengan membandingkan nilai hasil pretest dan post-test.

Menentukan kualitas keefektifan media yang dikembangkan menggunakan analisis tes hasil belajar berikut:

a. Uji Normalitas Data

Uji normalitas data penelitian ini melalui bantuan program SPSS dengan ketentuan hasil tes siswa baik pre-test atau post-test berdistribusi normal.

b. Menghitung Independent t-test

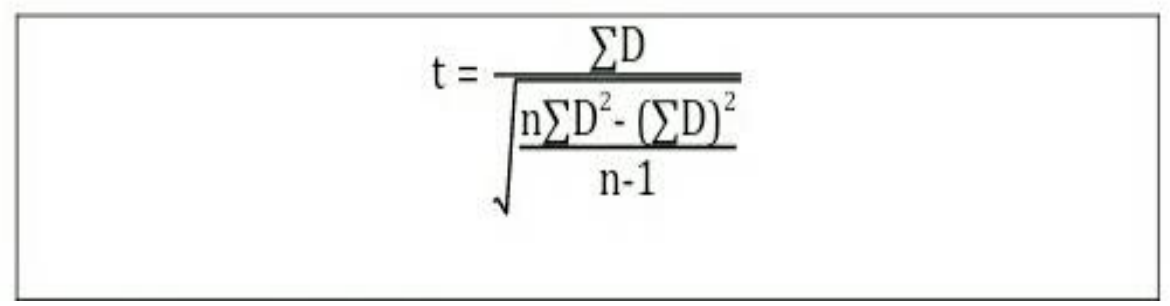

Gambar 7. Rumus t-test (Sunarti \& Selly, 2014:94) 


$$
\begin{aligned}
& \text { Keterangan: } \\
& \mathrm{t} \quad=\text { koefisien yang dicari } \\
& \mathrm{D} \quad=\text { Pebedaan skor kedua tes }\left(\mathrm{X}_{1}-\mathrm{X}_{2}\right) \\
& \Sigma \mathrm{D} \quad=\text { Jumlah perbedaan skor kedua tes } \\
& \mathrm{n} \quad=\text { jumlah subjek }
\end{aligned}
$$

\section{HASIL PENELITIAN DAN PEMBAHASAN}

Berdasarkan tabel penghitungan ahli media dapat disimpulkan bahwa skor total yang didapatkan yaitu 68 pada butir penilaian sebanyak 17 dengan rata-rata 4 . Apabila dikonversikan berdasar penilaian yang digunakan, skor 61 berada pada interval $X>3,5$. Berdasarkan konversi interval skor rerata kualitas materi yang dipakai mendapat nilai dengan kualifikasi sangat baik. Sementara itu, berdasarkan tabel 10. dapat disimpulkan bahwa skor total yang diperoleh yaitu 71 pada butir penilaian sebanyak 19 dengan rata-rata 3,73. Apabila dikonversikan berdasarkan penilaian yang digunakan, skor 75 berada pada interval $X>3,5$. Berdasar konversi interval skor rerata kualitas materi yang dipakai mendapat nilai dengan kualifikasi sangat baik.

Berdasar perolehan respons siswa yang dilakukan pada penguji cobaan kelompok kecil memperoleh skor total 107 dengan nilai presentase 93,8\%. Berdasarkan presentase pada rentang $85 \%-100 \%$, maka respons siswa terhadap media kartu bergambar 3 dimensi sebagai media pembelajaran keterampilan menulis teks berita memiliki kriteria sangat baik. Berdasarkan respons siswa yang dilakukan

\begin{tabular}{|c|c|c|c|c|c|c|}
\hline \multicolumn{7}{|c|}{ Tests of Normality } \\
\hline & \multicolumn{3}{|c|}{ Kolmogorov-Smirnov ${ }^{a}$} & \multicolumn{3}{|c|}{ Shapiro-Wilk } \\
\hline & Statistik & $d f$ & Sig. & Statistik & $\mathrm{df}$ & Sig. \\
\hline Pretest & 0.146 & 30 & 0.102 & 0.950 & 30 & 0.165 \\
\hline
\end{tabular}
pada uji coba lapangan diperoleh skor total 537 dengan nilai presentase $94 \%$.

\begin{tabular}{|c|c|c|c|c|c|c|}
\hline \multicolumn{7}{|c|}{ Tests of Normality } \\
\hline & \multicolumn{3}{|c|}{ Kolmogorov-Smirnov ${ }^{a}$} & \multicolumn{3}{|c|}{ Shapiro-Wilk } \\
\hline & Statistik & Df & Sig. & Statistik & df & Sig. \\
\hline posttest & 0.152 & 30 & 0.075 & 0.898 & 30 & 0.008 \\
\hline
\end{tabular}
Berdasarkan presentase pada rentang $85 \%-100 \%$, maka respon siswa terhadap kartu bergambar tiga dimensi sebagai media pembelajaran keterampilan menulis teks berita memiliki kriteria sangat baik.

Hasil perhitungan uji normalitas diketahui pada hasil pre-test nilai kolmogorov-smirnov sebesar 0,102 dan nilai shapiro-wilk 0,165 lebih tinggi dibanding dari taraf signifikansi 0,05. Maka, dapat diperoleh simpulan bahwa data pre-test pembelajaran teks berita berdistribusi normal. Pada perhitungan uji normalitas hasil 
post-test diketahui nilai kolmogorov-smirnov sebesar 0,075 dan nilai shapiro-wilk 0,008 Oleh karena itu, dapat diperoleh simpulan bahwa data post-test pembelajaran teks berita berdistribusi normal.

\begin{tabular}{|rl|r|r|r|r|}
\hline \multicolumn{2}{|c|}{ Class } & $\mathrm{N}$ & \multicolumn{1}{c|}{ Mean } & Std. Deviation & Std. Error Mean \\
\hline Hasil & Pretest & 30 & 63.4667 & 15.71236 & 2.86867 \\
& posttest & 30 & 83.8667 & 5.67957 & 1.03694 \\
\hline
\end{tabular}

Dari penghitungan menggunakan SPSS 16, didapatkan data kelas (pre-test) dengan jumlah responden memiliki rata-rata 63,4667 dan untuk kelas (post-test) dengan jumlah responden 30 memiliki rata-rata 83.8667. Setelah itu dilakukan perhitungan $t_{\text {hitung }}$ dengan menggunakan aplikasi SPSS 16 dengan hasil:

Independent Samples Test

\begin{tabular}{|c|c|c|c|c|c|c|c|c|c|c|}
\hline & & \multicolumn{2}{|c|}{$\begin{array}{c}\text { Levene's Test for } \\
\text { Equality of } \\
\text { Variances }\end{array}$} & \multicolumn{7}{|c|}{ t-test for Equality of Means } \\
\hline & & \multirow[t]{2}{*}{$\mathrm{F}$} & \multirow[t]{2}{*}{ Sig. } & \multirow[t]{2}{*}{$\mathrm{t}$} & \multirow[t]{2}{*}{ df } & \multirow[t]{2}{*}{$\begin{array}{c}\text { Sig. } \\
\text { (2-tailed) }\end{array}$} & \multirow[t]{2}{*}{$\begin{array}{c}\text { Mean } \\
\text { Difference }\end{array}$} & \multirow{2}{*}{$\begin{array}{c}\text { Std. } \\
\text { Error } \\
\text { Differen } \\
\text { ce }\end{array}$} & \multicolumn{2}{|c|}{$\begin{array}{l}95 \% \text { Confidence Interval } \\
\text { of the Difference }\end{array}$} \\
\hline & & & & & & & & & Lower & Upper \\
\hline \multirow[b]{2}{*}{ skor } & $\begin{array}{l}\text { Equal } \\
\text { variances } \\
\text { assumed }\end{array}$ & 20,409 &, 000 & $-6,688$ & 58 &, 000 & $-20,40000$ & 3,05033 & $-26,50590$ & $-14,29410$ \\
\hline & $\begin{array}{l}\text { Equal } \\
\text { variances } \\
\text { not } \\
\text { assumed }\end{array}$ & & & $-6,688$ & 34,451 &, 000 & $-20,4000$ & 3,05033 & $-26,58370$ & $-14,21630$ \\
\hline
\end{tabular}

Dari hasil penghitungan uji-t dapat dilihat $t_{\text {hitung }}$ adalah 6,688. Pada t tabel dengan derajat kebebasan ( $n-1) 29$ dengan taraf signifikansi 5\% yaitu 2,045. Mengartikan $t$ hitung lebih tinggi dari t tabel ( $t_{\text {hitung }}>t_{\text {tabel }}$ ) maka dapat dikatakan signifikan.

Berdasarkan nilai rerata yang berbeda di hasil tes sebelum menggunakan kartu bergambar tiga dimensi dan setelahnya, serta memiliki taraf signifikansi $0,000(0,00<$ $0,05)$ maka kesimpulannya kartu bergambar tiga dimensi efektif digunakan untuk media pembelajaran keterampilan menulis siswa.

Berdasarkan hasil penelitian yang diperoleh dan pemaparan hasil penelitian yang relevan dapat ditarik kesimpulan bahwa pengembangan kartu bergambar tiga dimensi sebagai media pembelajaran menulis teks berita valid berdasarkan penilaian para ahli yaitu ahli media dan ahli materi, media kartu bergambar tiga dimensi juga memiliki daya tarik tinggi berdasarkan angket respon siswa, dan media kartu bergambar 3 dimensi dikatakan efektif berdasar pada hasil tes yang diujikan kepada siswa.

Prosedur penelitian dan pengembangan ini digunakan model prosedural deskriptif Borg and Gall (Sugiyono: 2017). Model pengembangan dari Borg and Gall 
ini terdiri dari 6 tahap, yaitu: 1) Tahap persiapan dan pengumpulan datal, 2) Tahap Pengembangan, 3) Tahap Uji Coba Produk, 4) Tahap Revisi, 5) Tahap Uji Coba Lapangan 6) Tahap Desiminasi dan Implementasi.

Tahap pertama pada pengembangan ini adalah persiapan dan pengumpulan data. Pada tahap ini ada beberapa persiapan dan data yang diperoleh bedasarkan observasi yang telah dilakukan. Informasi pertama yakni hasil dari analisis kebutuhan, siswa membutuhkan media dalam pembelajaran menulis teks berita. Guru menyampaikan di setiap pembelajaran guru menggunakan metode ceramah, hal tersebut memiliki dampak pada siswa yang mengalami kejenuhan saat pembelajaran dan tidak adanya media pembelajaran yang menunjang materi. Oleh karena itu, maka perlu diadakannya pengembangan media pembelajaran pada keterampilan menulis siswa. Selanjutnya adalah informasi tentang kurikulum. Hasil yang diperoleh dari analisis kurikulum, SMP Negeri 1 Pleret Bantul menerapkan Kurikulum 2013. Adapun bagian yang dianalisis dari Kurikulum 2013 tersebut adalah Kompetensi Inti (KI), Kompetensi Dasar (KD), dan Indikator ketercapaian pada materi teks berita. Hasil dari analisis kurikulum tersebut dijadikan sebagai acuan pada proses pengembangan media untuk kegiatan belajar mengajar. Sedangkan informasi karakteristik peserta didik yaitu siswa SMP Negeri 1 Pleret Bantul berusia kisaran 13-15 tahun. Siswa SMP Negeri 1 Pleret Bantul juga memiliki tinggat daya tangkap yang berbeda-beda, maka kemampuan menulis mereka juga akan berbeda. Oleh karena itu, pengembangan kartu bergambar 3 dimensi diperlukan untuk diterapkan sebagai media dalam kegiatan belajar mengajar keterampilan menulis teks berita.

Tahap pengembangan. Pada tahap pengembangan terdiri atas penyusunan rancangan produk dan rencangan perangkat penilaian. Rancangan produk pada penilitian ini diperlukan langkah-langkah agar teratur. Langkah perancangan pembuatan kartu bergambar tiga dimensi meliputi pemilihan materi dan pemilihan gambar. Setelah kegiatan perancangan, peneliti melakukan perancangan instrumen penilaian. Instrumen tersebut terdiri atas penilaian ahli materi, penilaian ahli media, angket respons siswa, serta soal pre-test post-test.

Tahap uji coba produk. Tahap ini peneliti mengajukan instrumen penilaian dan media pembelajaran. Instrumen penilaian yang sudah jadi kemudian diajukan kepada validator untuk proses validasi dan instrumen dinyatakan layak digunakan, sedangkan soal pretest dan post-test diujicobakan di siswa kelas atas. Selanjutnya adalah tahap pengembangan kartu bergambar tiga dimensi. Setelah kartu bergambar tiga dimensi yang diedit dengan software corelDraw jadi, kemudian kartu bergambar tiga dimensi yang dikembangkan diteruskan pada ahli materi dan media guna diberikan penilaian.

Tahap selanjutnya yaitu uji coba tersebut diberikan pada ahli materi dan media guna dinilai. Hasil dari penilaian ahli materi memeroleh nilai rerata 4 pada kriteria "sangat baik", serta hasil penilaian ahli media memeroleh nilai rerata 3,73 pada kriteria "sangat baik". Dengan hasil tersebut maka pengembangan kartu bergambar tiga dimensi dinyatakan valid.

Tahap revisi produk. Pada tahap revisi produk media yang telah divalidasikan ke ahli materi dan media masih ada sedikit revisi. Berdasar saran dan masukan ahli media, media kartu bergambar tiga dimensi layak diujicobakan dengan sedikit revisi.

Tahap uji coba lapangan memiliki beberapa tahapan, yaitu uji coba produk, penyebaran angket respons siswa, dan melaksanakan tes. Pada tahap uji coba dilaksanakan dalam dua tahap, yakni pengujian pada kelompok kecil dengan menggunakan 6 siswa, dan pengujian lapangan dengan menggunakan 30 siswa kelas VIII G SMP Negeri 1 Pleret. Selanjutnya penyebaran angket respon siswa 
setelah penerapan media pembelajaran. Dalam pengujian kelompok kecil hasil dari angket ketertarikan siswa dengan nilai presentase $93,8 \%$ pada kriteria "sangat baik". Dalam pengujian kelompok besar, hasil ketertarikan siswa dengan media jika dipresetasikan mendapat nilai 94\% pada kriteria "sangat baik". Oleh karena itu, dapat disimpulkan siswa memiliki daya tarik tinggi dengan media kartu bergambar 3 dimensi yang dikembangkan.

Uji coba selanjutnya yaitu pre-test dan psot-test guna mengetahui efektivitas media yang diujikan sebagai media pembelajaran keterampilan menulis teks berita. Nilai tes siswa menunjukkan bahwa hasil tes berdistribusi normal.

Berdasarkan nilai rerata pre-test 63,46 dan post-test 83,86 memiliki perbedaan pada hasil tes sebelum menggunakan kartu bergambar tiga dimensi dan setelahnya, serta memiliki taraf signifikansi $0,000 \quad(0,00<0,05)$ maka disimpulkan kartu bergambar tiga dimensi yang digunakan sebagai media pembelajaran dalam kegiatan belajar mengajar materi keterampilan menulis teks berita efektif.

Tahap terakhir yaitu desiminasi dan implementasi. Tahapan ini adalah memublikasikan produk guna disosialisasikan pada keseluruhan subjek melalui berbagai platform publikasi ataupun pertemuan ilmiah yang tersedia. Setelah didesiminasikan, maka setiap sekolah dapat menggunakan produk tersebut di sekolah masing-masing.

Pengembangan kartu bergambar dimaksudkan guna meningkatkan keterampilan menulis teks berita siswa. Keterampilan menulis teks berita siswa diharapkan dapat meningkat setelah penggunaan media kartu bergambar tiga dimensi. Pengembangan kartu bergambar 3 dimensi mampu digunakan untuk alternatif media untuk menyampaikan materi. Hal ini serupa dengan penelitian Nur Azizah (2016) dengan berjudul "Pengembangan Media Pembelajaran Buku Bergambar Pada Mata Pelajaran Bahasa Indonesia Materi Menulis Puisi Siswa Kelas III Madrasah Ibtidaiyah Darussalamah Tajinan Malang". Hasil penelitian tersebut menyimpulkan bahwa pengembangan media pembelajaran buku bergambar memudahkan guru dalam mengajar bahasa Indonesia materi puisi dan dapat meningkatkan kemampuan siswa dalam menulis puisi sehingga memperoleh presentase $100 \%$.

Berdasarkan hasil penelitian penulis dan pemaparan hasil penelitian yang relevan dapat ditarik kesimpulan pengembangan kartu bergambar 3 dimensi sebagai media dalam pembelajaran menulis teks berita dapat diperoleh simpulan bahwa media yang dikembangkan valid berdasar penilaian para ahli, media kartu bergambar tiga dimensi juga memiliki daya tarik tinggi berdasarkan angket respon siswa, dan media kartu bergambar tiga dimensi dikatakan efektif berdasar pada hasil tes yang diujikan kepada siswa.

\section{PENUTUP}

Berdasar pada analisis data yang dilakukan dan pembahasan mendalam, maka hasil penelitian pengembangan ini dapat diperoleh simpulan penelitian ini menghasilkan pengembangan kartu bergambar 3 dimensi sebagai media pembelajaran keterampilan menulis materi teks berita di siswa kelas VIII SMP dengan memenuhi kriteria valid. Pengembangan kartu bergambar 3 dimensi untuk media pembelajaran keterampilan menulis berita pada siswa kelas VIII SMP apabila ditinjau dari ahli media memperoleh skor 71 dengan rata-rata 3,73 pada kualifikasi sangat baik. Apabila ditinjau dari ahli materi memperoleh skor memperoleh skor 68 dengan rata-rata 4 pada kualifikasi sangat baik. Daya tarik siswa berdasarkan angket yang dianalisis memperoleh skor 537 dengan nilai presentase 94\%. Berdasarkan presentase pada rentang $85 \%-100 \%$, maka respon siswa terhadap kartu bergambar 
tiga dimensi sebagai media pembelajaran keterampilan menyimak memiliki kriteria sangat baik. Efektivitas kartu bergambar tiga dimensi sebagai media pembelajaran menulis teks berita pada siswa kelas VIII SMP berdasarkan hasil tes mendapat rata-rata 83,86 jika dikonversikan menjadi data kualitatif termasuk dalam rentang $74,96<X \leq 94,88$ dengan kriteria baik. Dari taraf siginifikansi dengan uji-t diperoleh hasil t hitung adalah 6,688. Pada t tabel dengan derajat kebebasan 29 dan taraf signifikan $5 \%$ adalah 2,045. Berarti t hitung lebih besar dari t tabel (t-hitung $>T$-tabel). Maka, dapat ditarik kesimpulan bahwa penggunaan media kartu bergambar tiga dimensi sebagai media pembelajaran menulis teks berita efektif.

\section{DAFTAR PUSTAKA}

Anitah, Sri. (2010). Media Pembelajaran Surakarta:Yuma Pustaka.

Arsyad, A. (2017). Media Pembelajaran. Jakarta: Rajawali Press.

Azizah, Nur. (2016). Pengembangan Media Pembelajaran Buku Bergambar Pada Mata Pelajaran Bahasa Indonesia Materi Menulis Puisi Siswa Kelas III Madrasah Ibitidaiyah Darrusalam Tajinan Malang. Skripsi. Malang: FITK: UIN Maulana Malik Ibrahim Malang.

Jalinus, Nizwardi dan Ambiyar. (2016). Media dan Sumber Pembelajaran. Jakarta: Kencana.

Rahman, Taufiqur. (2018). Teks dalam Kajian Struktur dan Kebahasaan. Semarang: Pilar Nusantara.

Riyana, Cepi. (2012). Media Pembelajaran. Jakarta: Direktorat Jendral Pendidikan Islam Kementerian Agama Republik Indonesia.

Sardiman. (2012). Interaksi dan Motivasi Belajar Mengajar. Depok:Rajagrafindo.

Simarmata, Janner dkk. (2020). Elemen-Elemen Multimedia untuk Pembelajaran. Medan: Yayasan Kita Menulis.

Sugiyono. (2017). Metode Penelitian Pendidikan Pendekatan Kuantitatif, Kualitatif, dan R\&D. Bandung: Alfabeta.

Sumiharsono, Rudy dan Hasanah, Hisbiyatul. (2017). Media Pembelajaran. Jember: CV Pustaka Abadi.

Umayah. Siti, dkk. (2013). Pengembangan Kartu Bergambar Tiga Dimensi Sebagai Media Diskusi Kelompok Pada Pembelajaran IPA Terpadu. Unnes Science Education Journal. November 2013. Http://journal.unnes.ac.id/sju/index.php.usej (Diakses April 2018).

Undang-undang No.20 Tahun 2003 Tentang Sistem Pendidikan Nasional. (http://sindikker.dikti.go.id/dok/UU/UU20-2003-Sisdiknas.pdf, diunduh 28 April 2018) 
80 | Pengembangan Kartu Bergambar Tiga Dimensi...

Tabasa: Jurnal Bahasa, Sastra, dan Pengajarannya

Vol. 1, No. 1, Juni 2020 